\title{
РЕЛІГІЯ І РЕЛІГІЙНІСТЬ ЯК ФАКТОР НЕЛІНІЙНОСТІ РОЗВИТКУ СВІТ-СИСТЕМИ В УМОВАХ ГЛОБАЛІЗАЦІї
}

Проаналізовано вплив релігійних чинників на нелінійність розвитку світ-системи в ситуації глобалізаџії. Встановлено пряму залежність нелінійності розвитку світ-системи від здатності конкретного соціуму до сприйняття інновацій та модернізації. Досліджено ризики загострення міжрелігійних конфліктів та економічного занепаду у країнах периферії світ-системи, які пов'язані з кризою в окремих сферах суспільства, щуо відбувається на фоні впровадження результатів четвертої промислової револючііі.

Ключові слова: релігія, релігійність, християнство, протестантизм, іслам, бідність, суспільство, глобалізачія, світ-система.

Актуальність теми дослідження. Епоха постіндустріалізму ставить перед сучасним суспільством серйозні виклики, які проявляються у розмиванні персональних і особистих цінностей, етичній дезінтеграції, консюмеризмі, секуляризмі, стагнації економіки і політичному популізмі, занепаді розвитку освіти і науки. Внаслідок цього відбувається закономірна актуалізація впливу релігійних чинників на розвиток сучасного соціуму. У більшості робіт українських і зарубіжних учених проблематика впливу релігійного чинника на розвиток суспільства розглядається як відношення релігії до окремих соціальних підсистем - економіки, політики, сім’ї та інших інституцій. У них релігія інтерпретується як інституція, вплив якої є значно тривалішим і глибиннішим, ніж політичні рухи та ідеологічні цінності. Саме релігія визначає найбільш стійкі форми соціального устрою, його цивілізаційну специфіку, ментальні структури.

Проте стрімкий розвиток сучасного суспільства змінює традиційні релігійні референції і сама релігія в умовах формування інформаційного, постіндустріального суспільства та глобалізації проникає у соціально-політичну й економічну реальність країн світ-системи. В той же час жорстке протистояння у політичній економічній і технологічній сферах між країнами ядра та периферії світ-системи впливають і на активізацію релігійних інституцій у процесі їх вирішення, або хоча б послаблення. Зокрема, в окремих країнах периферії світ-системи відбувається не лише посилення впливу релігійного чинника на соціальну систему, а й простежується перетворення релігії на один з головних маркерів ідентифікаційних практик. Посилення такого впливу проявляється у збільшенні кількості релігійних рухів, які відстоюють не лише релігійні, а й соціальні, політичні та економічні інтереси, у посиленні пропаганди щодо необхідності релігійного виховання і освіти.

Поряд 3 цим, релігія та релігійні інституції починають набувати все більшої ваги у процесі формування громадянського суспільства i вироблення громадської думки, що проявляється в інституалізації релігійних інституцій на рівні міжнародних та міжурядових організацій як повноправних учасників міжнародної глобальної політики та міжнародних відносин. У той же час, в умовах погіршення економічної та політичної ситуації у світі, загострення екологічної та продовольчої кризи, посилення міжрелігійних та міжнаціональних конфліктів, неконтрольованих міграційних потоків та інших глобальних проблем сучасного соціуму, релігійний чинник стає ще більш вагомим інструментом розвитку суспільства. 3 огляду на важливість та глобалізаційний характер проблеми впливу релігійного чинника на розвиток світ-системи, світова спільнота змушена здійснювати пошук нових науковотеоретичних підходів для його вивчення.

Ступінь розробленості проблеми. Філософське осмислення впливу релігійних доктрин та інституцій на економіку, політику та інші сфери суспільного життя вимагає акумулювання напрацювань різних галузевих дисциплін, в межах яких вивчається проблематика ваги релігійного чинника у подоланні економічної відсталості, бідності, голоду, військових конфліктів, демографічної кризи. Дослідження специфіки виявлення релігійних чинників у суспільному розвитку стало предметом зацікавленості П. Бергера, 3. Бжезинського, М. Вебера, Е. Дюркгайма, А. Тойнбі, Е. Троельча, С. Хантінгтона, Л. Харрісона, О. Шпенглера та ін. На сучасному етапі науковими розвідками впливу релігійного фактору у глобалізованому світі займаються М. Ахмад, Р. Барро, П. Боетке, М. аль-Газалі, Р. Інглхарт, Т. Куран, Р. МакКлірі. Серед українських дослідників, які вивчають проблематику впливу релігії на розвиток глобалізованого суспільства, доречно назвати Є. Дулумана, С. Здіорука, М. Іващенко, В. Сленського, К. Кислюка, Н. Ковтун, М. Козловця, А. Колодного, П. Кралюка, О. Кучера, О. Сагана та ін.

Ще на початку минулого століття філософ і протестантський теолог Е. Троельч спробував пояснити зміни впливу релігії шляхом опису історичної еволюції ролі релігії у суспільстві. Він доводив, що 
Ренесанс в Італії у XVII столітті та наукова революція стали поштовхом для початку нового історичного періоду, який триває зараз, а протестантизм відклав його, а не підштовхнув. Е. Троельч розглядав протестантизм як просту модифікацію католицизму, в якій було збережено католицьке формулювання проблем. При цьому протестантизм пропонував іншу відповідь щодо їх вирішення [1:21]. Філософ часто писав, що зміни у суспільстві є загрозою для християнської релігії [2: 9]. Ці тенденції на даний час якнайповніше засвідчує розвиток окремих країн ядра світ-системи, в яких по мірі розвитку суспільства релігія трансформується, але жодним чином не зникає.

Кардинально протилежне розуміння релігії в цілому, й протестантизму зокрема, запропонував німецький філософ і соціолог М. Вебер, який позиціонував у праці "Протестанська етика i дух капіталізму" релігію як один з ключових факторів розвитку суспільства. Філософ не лише розкрив вплив релігійних чинників на економічну діяльність суспільства, а й проаналізував соціальну стратифікацію й відмінні риси розвитку цивілізацій. Він стверджував, що протестантські, насамперед кальвіністські, релігійні ідеї здійснили значний вплив на соціальні інновації та розвиток економічної системи Заходу [3]. На думку вченого, крайній аскетизм щодо використання коштів на придбання предметів розкоші, як перешкода на шляху до споживання нажитого багатства, неминуче повинен був служити його продуктивному використанню в якості інвестованого капіталу. Існування такого типу релігії знайшло відображення у "протестантській етиці", яка здійснила значний вплив на розвиток сучасного світу. Аналіз, проведений М. Вебером, сприяв розумінню проблеми впливу релігії на економічний розвиток.

Проте уже в XXI ст. у праці "Священна і світська: релігія і політика у всьому світі" американські вчені-соціологи Р. Інглхарт та П. Норріс, аналізуючи дані за 1981-2001 роки, зібрані у 78 країнах світу, розглядають релігійність у більш широкому контексті. Вони доводять, що релігійний чинник найбільш виявляє себе серед незахищених верств населення, особливо у найбідніших країнах і неспроможних державах, які зіштовхуються із небезпечними для життя ризиками [4]. Відтак, релігія не може розглядататись як визначальний чинник розвитку економіки та подолання економічної відсталості. В той же час український філософ та історик В. Сленський звертає увагу на відродження впливу релігійного фактору у сучасному глобалізованому світі, концентруючи увагу на пробудженні релігії у посткомуністичному світі, на католицькому, євангелічному та ісламському піднесенні, а відтак загостренні релігійного екстремізму і терору. При цьому привертає увагу думка автора про тісний взаємозв'язок між релігійним чинником та суспільно-політичними перетвореннями, які відбуваються в Україні [5]. Незважаючи на значну зацікавленість сучасних авторів тематикою впливу релігійних чинників на нерівномірність розвитку світ-системи, проблема вивчення впливу релігійного фактору на розвиток різних сфер соціальної буттєвості людини у найбідніших та слаборозвинутих країнах світу у контексті глобалізаційних процесів залишається актуальною проблемою соціально-філософського аналізу.

Метою статті є дослідження релігії та релігійності як важливих факторів нелінійності розвитку світсистеми в умовах глобалізаційних процесів.

Виклад основного матеріалу. У контексті аналізу впливу релігійного фактору на нелінійність розвитку сучасної світ-системи методологічно затребуваними залишаються концептуальні положення М. Вебера, який доводив, що аскетичний протестантизм став вирішальним аспектом у становленні капіталізму та індустріального суспільства. У праці "Господарська етика світових релігій" філософ досліджує питання, чому лише Європі вдалося досягнути потужного економічного розвитку, що обумовило поворот у світовому розвитку в сторону індустріального суспільства, та чому розвиток Заходу і Сходу пішов різними шляхами. На думку автора, Реформація змінила відношення до праці, визнавши іiі істинною службою Богові, що призвело до інтенсифікації господарського життя, а в кінцевому результаті - до соціально-економічного прориву Заходу [6]. Протестантизм зумів забезпечити виникнення економічної системи з соціальною мобільністю і соціальним розшаруванням, став духовною основою економіки, що базується на швидкому технічному зростанні і розширенні виробництва у прагненні отримати прибутки від капіталовкладень. Натомість основною перешкодою для успішного розвитку економіки у країнах Сходу був традиціоналізм життя, менталітет і релігія.

У свою чергу А. Тойнбі, аналізуючи історичний розвиток цивілізацій Сходу, зосередив свою увагу на аналізі впливу релігії на розвиток східних суспільств. Творча меншість, погляди і думки якої знаходять відображення в релігії, стає одним із рушійних механізмів старої цивілізації і одночасно авангардом для виникнення нової [7]. Історичний розвиток сучасних країн ядра світ-системи підтвердив основні положення праць М. Вебера і А. Тойнбі. У науковій літературі напрацьована значна статистична база, яка підтверджує ідеї вчених і дає можливість стверджувати, що причини відсталості і розвитку країн світсистеми криються не лише в історичних, географічних, демографічних й економічних чинниках, а й у тій релігії, яку сповідує більшість населення країни.

За даними Організації Об’єднаних Націй (OOH) та Міжнародного валютного фонду (МВФ) на перших позиціях у рейтингах країн по номінальному валовому внутрішньому продукту (ВВП) із значними показниками перебувають переважно протестантські країни, наприклад у 2018 році на 
першому місці були США з показником 20413 млрд. доларів [8]. Серед країн, які перебувають у першій двадцятці по реальному ВВП за 2014 рік є дев'ять країн (Норвегія, Швейцарія, США, Нідерланди, Австралія, Австрія, Швеція, Німеччина, Канада), населення яких переважно протестанти. Це один із прикладів позитивного впливу релігії на розвиток економіки країни. Разом з тим у цій двадцятці немає жодної православної країни. Православ’я як найбільш консервативна і ортодоксальна гілка християнства, не пішла шляхом модернізації на основі принципів раціоналізму і прагматизму, який свого часу був обраний протестантами. Традиційно у православ’ї матеріальне багатство протиставляється духовному багатству та матеріальній бідності, у той час як у протестантизмі бажання бути бідним засуджується. Трудові обов'язки для протестантів-це обов'язок як перед Богом, так і перед суспільством, для православних праця в першу чергу має бути духовною, а матеріальна праця, пов'язана 3 вигодою, прагненням до збагачення, гординею, визнається марнославством. Окрім того, через вплив візантійської традиції православ'я містить у собі й елемент азійського фаталізму, панування держави над соціумом i особистістю, безвідповідальність влади перед суспільством, а відтак знижений рівень особистої відповідальності та ініціативності членів суспільства, що, в свою чергу, гальмує розвиток економіки та періодично призводить до соціальних катаклізмів, економічних криз і революцій.

3 рівнем соціально-економічного розвитку протестантських країн можна співвіднести показники окремих країн Азії. Південна Корея, Сінгапур, Гонконг і Тайвань ("Азійські тигри"), які у недалекому минулому були досить бідними країнами. Проте на сьогоднішній день вони стали успішними індустріальними країнами, а за окремими показниками уже перейшли до когорти постіндустріальних країн на рівні з країнами Єврепойського Союзу, США та Японії. Процес їх модернізації супроводжувався підвищенням рівня релігійності населення. Так, понад $25 \%$ жителів Південної Кореї перейшли в протестантизм. Причинами цих процесів називають катастрофічні потрясіння у суспільстві, пов'язані із війною та економічною відсталістю країни, яка на почаку 1960-х років була однією 3 найбідніших країн Східної Азії і здійснила ривок, який серед вчених економістів вважається одним з найкращих прикладів транзиту із країн периферії до напівпериферії світ-системи. Диктатура у Південній Кореї закінчились із обранням президентом країни пресвітера сеульської церкви 25 років тому. За цей час протестанти, керуючись своїм авторитетом та активністю, через моральну атмосферу суспільства змогли так вплинути на економічний розвиток країни, боротьбу з корупцією, політичну систему, виховний та освітній процеси, що Південна Корея стала однією з постіндустріальних країн серед "Азійських тигрів".

Проте показники ВВП та індексу людського розвитку (ІЛР) по іншим країнам цієї групи також схожі iз показниками протестантських та католицьких країн, водночас переважна частина їх населення $\epsilon$ прихильниками буддизму. Розрахунок у цих країнах був зроблений на виробництво експортноорієнтованої конкурентоздатної продукції, насамперед у сфері легкої промисловості, що потребувало невеликих капіталовкладень та значних трудових ресурсів, яких у цих країнах достатньо. Працьовитість $і$ старанність, виховані на базі буддизму, сприяли успіхам "Азійських тигрів". Населення цих країн зберегло свою культуру і традиції, поставивши їх на службу нарощуванню економічної могутності. Вони побороли головну перешкоду розвитку будь-якої країни-корупцію, та відмовились від найбільш капіталоємних та непомірних витрат на озброєння та мілітаризацію. Разом із тим інвестиційні вкладення у людський капітал, поряд з інвестиціями в економіку, стали основою економічного дива у Сінгапурі, Гонконзі та Тайвані, які були підтримані іноземними дотаціями, що заохочувалося урядами цих країн через послаблення оподаткування бізнесу, жорсткий контроль за дотриманням норм міжнародного законодавства, покарання за його порушення і прояви корупції та інші преференції. Науковці пов'язують такий розвиток із ментальністю соціуму цих країн, яка базується на споглядальних релігіях Сходу, на ідеях традиціоналізму й патерналізму, пошани до старших, слухняності і працелюбстві.

Водночас у сучасних умовах проголошеної четвертої промислової революції таких чинників недостатньо для створення новітніх технологій і фундаментальних відкриттів у науці. Динаміка процесів духовного розвитку азійсько-тихоокеанського регіону у науково-філософської спільноти викликає сьогодні значну зацікавленість, оскільки в регіоні склалося складне і специфічне економічно-соціальне середовище. Світоглядний та релігійний чинник населення регіону здійснює безпосередній вплив на динаміку процесів модернізації і соціальних перетворень. У ситуації наростаючої глобалізації та інтенсивних технологічних змін представникам східних цивілізацій необхідно переосмислювати національні традиції та екзистенційні проблеми буття, змінюючи ставлення до економічних, трудових відносин і принципів конкуренції. Інноваційні успіхи країн напівпериферії азійсько-тихоокеанського регіону значною мірою пояснюються відповідною трудовою i соціальною етикою, зокрема працелюбством, прагненням до самореалізації, умінням самообмежуватися та вірністю традиціям. Відтак ефективний економічний розвиток цих країн обумовлені тим, що буддизм, конфуціанство, даосизм актуалізують мобілізаційні зусилля суспільства. Таким чином, інтеграція і синтез традиційних східних релігій виробили продуктивний синтез релігійно-етичних переконань, ідеології та світогляду, які сприяли раціональному типу господарювання, і довели, що використовувати його можуть не лише протестанти. 
При цьому статистичні дані міжнародних організацій не дозволяють ігнорувати і той факт, що у країнах ядра світ-системи, які зазвичай $\epsilon$ християнськими, простежується зв'язок соціальноекономічного розвитку зі зростанням рівня атеїзму. Цей зв'язок обумовлюється тим, що високий рівень економічного розвитку та якості життя, комфортні умови проживання і новітні технологічні досягнення зменшують потребу людини і суспільства в цілому у духовній підтримці, яку дає релігія. Однак, ще рано говорити про стійкий зв'язок між соціально-економічним розвитком і рівнем атеїзму у сучасному глобалізаційному світі. У багатьох високорозвинутих країнах частка атеїстів не значна, існує лише 4 країни, у яких атеїсти складають більшу частину населення. Серед країн ядра світ-системи - це Швеція та Японія, напівпериферії - Чехія, периферії - В’єтнам.

На противагу зростання рівня атеїзму у деяких країнах, в умовах посилення глобалізаційних процесів в останні роки з'явився і новий чинник зростання релігійності у світі. Він пов'язаний з результатами четвертої індустріальної революції (Industry 4.0.), внаслідок якої поряд 3 новітніми технологічними відкриттями, роботизацією й інтернетизацією виробництва посилюються процеси некерованої стихійної міграції та відбувається паралельне формування як закритих етнічних діаспор, так і подальше посилення процесів взаємопроникнення етносів і соціокультурних традицій. Прямим наслідком цих тенденцій є ускладнення міжетнічних та міжцивілізаційних відносин. Багатьом суспільствам загрожує загострення міжрелігійних конфліктів, економічний занепад та руйнування ознак цивілізації. На сьогоднішній день така загроза існує у країнах периферії світ-системи, до яких належать найбідніші країни Африки.

Економічна криза, яка панує останні десятиліття у найбідніших країнах Африки, призвела до серйозної еволюції африканського ісламу, який різко посилив свій вплив у політичному житті. На сьогоднішній день у арабських країнах проживає лише 18 \% мусульман, при цьому близько половини всіх мусульман світу проживає у північно-західній частині Африки. Зростання поширення і посилення впливу ісламу у країнах периферії пояснюється особливостями його релігійної системи, яка полягає у "молодості" цієї релігії, її войовничості, наступальному характері та, водночас, у гнучкості, динамізмі та тотальності, яка охоплює всі сфери життя суспільства, у тому числі і економіку. У ряді країн Африки прихід до влади ісламських реформістів був пов'язаний з лозунгами, які проголошував новий режим, що включали "створення морального кодексу суспільного порядку, зменшення соціальної нерівності, право на працю для всіх" [9: 118]. Разом із тим, в умовах глобалізаційних процесів та модернізації, ключовими чинниками зростання кількості мусульман у країнах Африки є економічні стимули та політична доцільність. Багаті нафтодобувні країни Перської затоки, які зацікавлені у посиленні позицій ісламу у світі, реалізують політику надання грантів і безпроцентних кредитів країнам, населення яких сповідує іслам. Відтак у країнах Африки, які, після отримання незалежності, будували свої економічно-політичні відносини з країнами Близького Сходу, кількість населення, яка сповідує іслам, зросла більше, ніж у два рази. На даний час, коли впровадження Субсахарської Африки у міжнародну економічну систему i систему відносин між високорозвинутими країнами не відбулося, саме через релігійний чинник вона продовжує залишатися світовим контингентом та продовжує зв'язки із світом. Демографи-мусульмани у країнах південної Африки стверджують, що іслам є найбільш швидкозростаючою релігією на материку. Наприклад, у Південно-Африканській Республіці (ПАР) кількість мусульман з 1991 року зросла у 6 разів, а у Руанді кількість мечетей з 1994 року зросла у 2 рази [10]. Такі динамічні зміни викликають новий поглиблений інтерес до нерівномірного поширення ісламу в інших країнах Африки, де переважає християнство, а конфесії корінних народів відступають. При цьому подальше поширення та поглиблення ісламу в окремих країнах Африки веде до міграції християнського населення з цих країн. Наприклад, у ПАР саме цей контингент свого часу забезпечив високу якість праці і підприємництва, які сприяли стабільності зростання ВВП країни, створенню новітніх технологій у промисловості та сільському господарстві. Традиційно у християнських країнах ядра світ-системи проявляється хвилювання через посилення впливу ісламу у Субсахарській Африці, оскільки у країнах периферії є дві течії ісламу, які, вважаючи себе очищеними, бойовими, критикують традиційну владу, та радикальний ісламізм, який одночасно веде боротьбу проти влади, чиновників, корупції, інших релігій, імперіалізму та глобалізації. Ісламські угрупування, які потрапили під вплив радикальних ісламістів Сходу, стають на сьогоднішній день значною силою в Африці. При цьому не лише діяльність радикальних організацій активізує ісламський радикалізм в окремих країнах Чорної Африки, а й жахлива бідність, голод, нестача прісної води, хвороби та політичний хаос, який підсилюється корупцією на всіх рівнях влади у цих країнах. Проте така безвихідь і відсталість була також причиною широкого поширення християнства у країнах ядра світ-системи, саме релігія формувала етику праці та ментальність народів внаслідок чого різні країни виявилися по-різному готовими до інноваційної постіндустріальної економіки.

Висновки. Таким чином, взаємозв'язок релігійних чинників і розвитку світ-системи вказує на багатовекторний і суперечливий вплив релігії та релігійних цінностей на розвиток економіки, політики, права та інших сфер соціального буття сучасної людини. Вплив релігійних чинників на розвиток суспільства прямо залежить від конкретних аспектів, які орієнтують соціум на прогрес, інновації та модернізацію. Релігійний чинник залишається важливим фактором економічного і соціально- 
політичного розвитку країн світ-системи. Саме релігійно-етичні світоглядні позиції дозволили одним країнам перейти з периферії світ-системи до її центру, а в інших законсервували соціально-економічну відсталість. Динаміка релігійності у світі на даний час обумовлена кризою в окремих сферах суспільства, яка відбувається на фоні модернізації, розвитку новітніх технологій, роботизації та діджиталізації, що $є$ результатами четвертої промислової революції, та призвела до його різкої поляризації, падіння рівня добробуту значної частини населення і нездатності адаптуватися до нових соціальних умов. Пов'язані 3 цим економічні та політичні кризи, масове зубожіння, неконтрольовані міграційні процеси загрожують загостренням міжрелігійних конфліктів та економічним занепадом. На сьогоднішній день така загроза існує у ряді країн периферії світ-системи. Тому проблематика впливу релігійних чинників на нелінійність розвитку світ-системи в умовах глобалізації та впровадження концепції четвертої промислової революції набуває потреби більш детального і глибокого соціально-філософського аналізу, насамперед, у контексті з'ясування впливу православ'я на соціально-економічний і політичний розвиток країн і Східної Свропи.

\section{СПИСОК ВИКОРИСТАНИХ ДЖЕРЕЛ ТА ЛІТЕРАТУРИ}

1. Troeltsch E. Protestantism and Progress / E. Troeltsch (Translated by W. Montgomery, 1958, Original titl : Die Bedeutung des Protestantismus für die Entstehung de modernen Welt). - Continuum - 1958. -59 p.

2. Rubanowice R. J. Crisis in Consciousness : The Thought of Ernst Troeltsch / Robert J. Rubanowice. - Tallahassee : University Presses of Florida. - 1982.

3. Вебер М. Протестантская этика и дух капитализма. Избранные произведения / Макс Вебер. - Перевод с немецкого и общая редакція : Ю. Н. Давыдов. - М. : Прогресс, 1990. - 271 с.

4. Inglehart R. F. Sacred and Secular : Religion and Politics Worldwide/ Ronald F. Inglehart, Pippa Norris. Cambridge University Press, 2004.

5. Сленський В. Велике повернення: релігія у глобальній політиці та міжнародних відносинах кн. ХХ - поч. XXI ст. / В. Сленський. - Львів : Видавництво УКУ, 2013. - 504 с.

6. Вебер М. Хозяйственная этика мировых религий. Опыты сравнительной социологии религии. Конфуцианство и даосизм / М. Вебер. - Пер. с нем. и предисл. О. В. Кильдюшова. - СПб. : Владимир Даль, 2017. $-446 \mathrm{c}$.

7. Тойнбі А. Дослідження історії. Том 1-2. / Арнольд Дж. Тойнбі. - К. : Основи, 1995. - 614 с.

8. Report for Selected Countries and Subjects [Electronic resource] // The International Monetary Fund and the World Bank. - 2018. - Access mode : http:/www.imf.org/external/pubs/ft/weo/2018/01/weodata/weorept.aspx?sy=2017\&ey=2018\&scsm.

9. Bayart J. Religion and Political Modernity in Black Africa [report]. African Studies Papers/JeanFrançois Bayart. - Paris : Karthala, 1993. - 264 p.

10. Itano N. In South Africa, Many Blacks Convert to Islam [Electronic resource] / N. Itano // The Christian Science Monitor. - 2012. - Access mode : https://www.csmonitor.com/2012/0110/p13s1-woaf.html.

\section{REFERENCES (TRANSLATED \& TRANSLITERATED)}

1. Troeltsch E. Protestantism and Progress / E. Troeltsch (Translated by W. Montgomery, 1958, Original titl : Die Bedeutung des Protestantismus für die Entstehung de modernen Welt). - Continuum - 1958. -59 p.

2. Rubanowice R. J. Crisis in Consciousness : The Thought of Ernst Troeltsch / Robert J. Rubanowice. - Tallahassee : University Presses of Florida. - 1982.

3. Veber M. Protestantskaia etika i dukh kapitalizma. Izbrannyie proizvedeniia [Protestant Ethics and the Spirit of Capitalism. Selected Works] / Maks Veber. - Perevod s nemetskoho i obshchaia redaktsiia : Yu. Davydov - M. : Prohress, 1990. - 271 p.

4. Inglehart R. F. Sacred and Secular : Religion and Politics Worldwide / Ronald F. Inglehart, Pippa Norris. Cambridge University Press, 2004.

5. Yelenskyi V. Velyke povernennia : relihiia u hlobal'nii politytsi ta mizhnarodnykh vidnosynakh kn. XX - poch. XXI st. [Great Return : Religion in Global Politics and International Relations, End of $20-$ Beg. of the 21 Century] / Viktor Yelenskyi. - L'viv : Vydavnytstvo UKU, 2013. - $504 \mathrm{~s}$.

6. Veber M. Khoziaistvennaia etika mirovykh relihii. Opyty sravnytel'noi sotsiolohii relihii. Konfutsianstvo i daosizm. [Economic Ethics of World Religions. Experiments Comparative Sociology of Religion. Confucianism and Taoism] / Maks Veber. - Per. s nem. i predisl. O. V. Kyldiushova. - SPb. : Vladymyr Dal, 2017. - 446 s.

7. Toinbi A. Doslidzhennia istorii [The Research of the History] / Arnold Toinbi. - Tom 1-2 - K. : Osnovy, 1995. $614 \mathrm{~s}$.

8. Report for Selected Countries and Subjects [Electronic resource] // The International Monetary Fund and the World Bank. - 2018. - Access mode : http://www.imf.org/external/pubs/ft/weo/2018/01/weodata/weorept.aspx?sy=2017\&ey=2018\&scsm.

9. Bayart J. Religion and Political Modernity in Black Africa [report]. African Studies Papers/JeanFrançois Bayart. - Paris : Karthala, 1993. - 264 p.

10. Itano N. In South Africa, Many Blacks Convert to Islam [Electronic resource] / N. Itano // The Christian Science Monitor. - 2012. - Access mode : https://www.csmonitor.com/2012/0110/p13s1-woaf.html. 


\section{Венцель Н. В. Религия и религиозность как фактор нелинейности развития мир-системы в условиях глобализации.}

Проанализировано влияние религиозных факторов на нелинейность развития мир-системы в ситуации глобализации. Установлена прямая зависимость нелинейности развития мир-системы от способности конкретного сочиума к восприятию инноваций и модернизации. Исследованы риски обострения межрелигиозных конфликтов и экономического упадка в странах периферии мир-системы, которые связанны с кризисом в отдельных сферах общества, что происходит на фоне внедрения результатов четвертой промышленной револючии.

Ключевые слова: религия, религиозность, христианство, протестантизм, ислам, бедность, общество, глобализаџия, мир-система.

\section{Ventsel N. V. Religion and Religiosity as a Factor of the Nonlinearity of the Development of the World- System in the Conditions of Globalization.}

The influence of religious factors on the nonlinearity of the world system development in the context of globalization processes is analyzed. It is determined that the interrelation of religious factors and the development of the world system points to the multi-vector and contradictory influence of religion and religious values on the development of the economy, politics, law and other spheres of social life of a modern man. It is religious and ethical worldview positions that allowed one countries to move from the periphery of the world-

system to its center, while in others they have preserved socio-economic backwardness. The dynamics of religiosity in the world at the present time is determined by the crisis in certain spheres of society that occurs against the backdrop of the fourth industrial revolution. This crisis led to a sharp polarization of society, a decline in the well-being of a large part of the population and an inability to adapt to the new social conditions.

The associated economic and political crises, massive impoverishment, uncontrolled migration processes threaten the intensification of interreligious conflicts and the economic decline of society. To date, such a threat exists in a number of countries in the periphery of the world-system. Therefore, the problematic of the influence of religious factors on the nonlinearity of the development of the world-system in the context of globalization and the introduction of the concept Industry 4.0. acquires the needs of a more detailed and profound sociophilosophical analysis, primarily in the context of elucidating the influence of Orthodoxy on the socio-economic and political development of the countries of Eastern Europe.

Key words: religion, religiosity, Christianity, Protestantism, Islam, poverty, society, globalization, the worldsystem. 